\title{
Triumphs and tribulations of COVID-19 vaccines: Lessons to be learned from smallpox epidemics in the 1700s
}

\author{
Ambrogio Fassina ${ }^{1}$ (1) $\cdot$ Matteo Fassan ${ }^{1} \cdot$ Giorgetta Bonfiglio Dosio ${ }^{2} \cdot$ Luisa Barzon $^{3}$ \\ Received: 17 December 2020 / Revised: 28 December 2020 / Accepted: 3 January 2021 / Published online: 12 January 2021 \\ (C) The Author(s), under exclusive licence to Springer-Verlag GmbH, DE part of Springer Nature 2021
}

The recent years have been threatened by emerging and reemerging pathogens, like influenza viruses, Ebola virus, Zika virus, and, currently, SARS-CoV-2, which have rapidly spread globally causing large epidemics with devastating health and economic consequences. These health emergencies dramatically resemble the dreadful epidemics occurring in the pre-antibiotics and pre-vaccine era, like plague and smallpox, whose elimination represented important conquests for humanity. New technologies are allowing the rapid development of effective prophylactic vaccines, the key weapons to defeat the virus, a goal that have been achieved with unprecedented efforts and speed for COVID-19 [1]. As to 10 December 2020, according to World Health Organization landscape documents, 52 COVID-19 candidate vaccines are in clinical evaluation (13 in phase 3 clinical trials) and 162 in preclinical evaluation. Results of phase 1 and 2 clinical trials have been published for inactivated whole virus vaccines, recombinant adenovirus vectored vaccines (rAd5-, rAd26-, and chimpanzee ChAdOx1-vectored vaccines), mRNA vaccines (mRNA1273 and BNT162b2), and recombinant SARS-CoV-2 spike protein nanoparticle vaccine, which showed the acceptable safety profile and high immunogenicity of all vaccines [1].

In addition, results from phase 3 clinical trials with mRNA vaccines show over $90 \%$ efficacy at preventing COVID-19 [2, 3]. However, these efforts are likely to be frustrated because of the pervasive misinformation about COVID-19 vaccines and

This article is part of the Topical Collection on Quality in Pathology

Ambrogio Fassina

ambrogio.fassina@unipd.it

1 Department of Medicine, Surgical Pathology \& Cytopathology Unit, University of Padua, Padua, Italy

2 Department of Historical and Geographic Sciences and the Ancient World, University of Padua, Padua, Italy

3 Department of Molecular Medicine, Microbiology Unit, University of Padua, Padua, Italy the influence of the anti-vaccine movement in the media, which undermine vaccine confidence $[4,5]$.

Even this anti-vaccine conspiracy is not novel in human history. It represented a major obstacle in defeating smallpox, a viral disease that killed between $15 \%$ and $30 \%$ of infected individuals and was eradicated thanks to vaccination. The attitude and debate against the first immunization practices were well documented by a little-known anecdotal case from Padua, in the Venetian Republic in the 1700s: Abbot Pietro Ceoldo, who wrote a few lines in the margins of his 1788 printed liturgical calendar. These handwritten lines describe the variolation procedure, which was courageously performed by countess Arpalice Papafava to protect her 4-year-old son Alessandro. The child was engrafted with the purulent discharge from one of her healing servants; seven days after the inoculation, he developed fever and some pustules, but recovered rapidly and completely (Fig. 1) [6]. Countess Arpalice decision went against the attitude of general practitioners, of the medical and academic community, of the Church, and of mostly the common people who demonstrated violent opposition to smallpox inoculation [7].

European aristocracy and literate people were better informed of variolation validity, and indeed also, the Papafava family knew of the procedure by Lady Mary Wortley Montagu [8]. Lady Mary travelled a lot, and during one of her frequent visits to Venice, she resided in Padua for a few months probably as an acquaintance to the Papafava family who subsequently taught countess Arpalice how to perform the variolation. Indeed, only few books and scientific reports, occasional accounts from England, France, and Turkey, and military armies, along with revolutionary and anticlerical ideas, brought all around Europe the practice of variolation from Middle East countries, mainly Turkey.

The energetic Lady Montagu also found fierce resistance, but eventually succeeded in the dissemination of her experience with the cure of the Crown family [8]; until in 1796, Edward Jenner realised the definitive solution, using cowpox material for smallpox vaccination. A similar story occurred for 
Fig. 1 Handwritten notes reporting the inoculation of count Alessandro aged 4, performed by his mother Arpalice, with a serious complication (almost dead for three hours), followed by pustules and fever, but with complete recovery. Front page of the liturgical calendar with the year 1788 (insert).

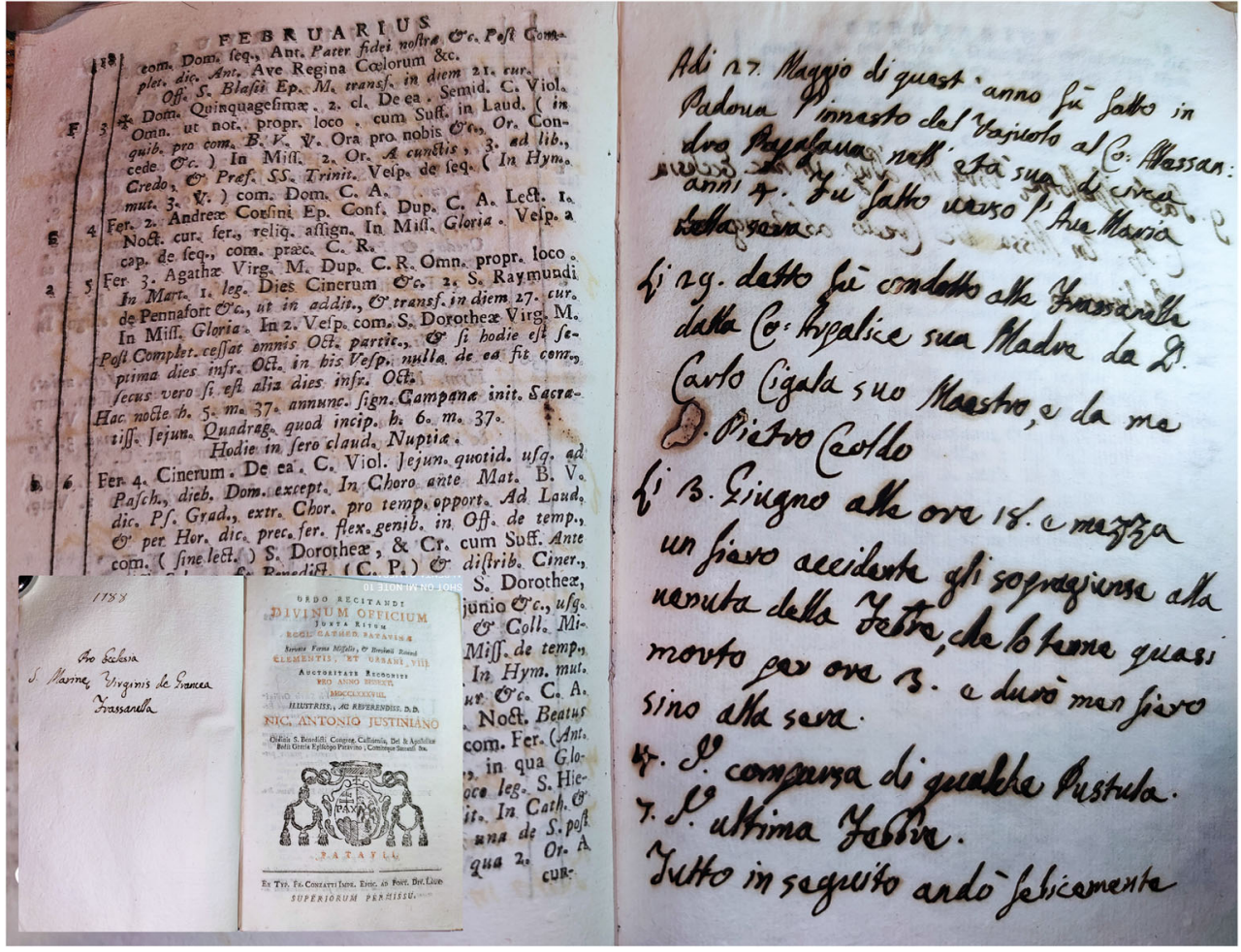

polio vaccination, which was hardly accepted 50 years ago, with Africa nowadays been declared free.

Definitely, the history of vaccination is fascinating for its so different involvements in research, social attitudes, and single individual lives, but never as in these very days information has so diffusely struck the world population, reviving all sorts of pro and against reactions as in the past $[4,5]$.

Beyond science, medical doctors at a patient's bed and basic scientists directly or indirectly involved in the fight against the present pandemic must share the responsibility of the communication to media and to commons of their scientific findings and of their personal opinions. It is not like as three hundred years ago, when the first variolation documented reports by the two Padua University scholars Emmanuel Timoni (1713) and Jacob Pylarino (1714) could be known only by the few selected readers of the Philosophical Transactions $[9,10]$.

Careful attention must be paid in the choice of wording and conclusion, with the clear foresight that everything will immediately be mis-used both by fervent supporters and by acrimonious opponents, with clamorous amplification in newspapers, radio, and television. Politicians will then be obliged to take their pertinent consequences and drastic solutions, following the rancorous manifestation of common people resentments, or the suggestion of the quiet and prudent voices of truly illuminated science.

Acknowledgements The authors are grateful to Countess Francesca Papafava for the kind permission to examine the original documents from the Papafava Antonini dei Carraresi Archives in Villa di Frassenelle (Padova, Italy).

Author contributions AF and LB drafted the manuscript. GBD provided the historical sources. AF, LB, and MF edited and revised the manuscript and approved the final version.

\section{Compliance with ethical standards}

Conflict of interest The authors declare that they have no competing interests.

\section{References}

1. Poland GA, Ovsyannikova IG, Kennedy RB (2020) SARS-CoV-2 immunity: review and applications to phase 3 vaccine candidates. Lancet. 396(10262):1595-1606

2. Callaway E (2020) COVID vaccine excitement builds as Moderna reports third positive result. Nature. 587(7834):337-338

3. Polack FP et al (2020) C4591001 Clinical Trial Group. Safety and efficacy of the BNT162b2 mRNA Covid-19 vaccine. N Engl J Med. https://doi.org/10.1056/NEJMoa2034577

4. Horton R (2020) Offline: managing the COVID-19 vaccine infodemic. Lancet 396(10261): 1474

5. Burki $\mathrm{T}$ (2020) The online anti-vaccine movement in the age of COVID-19. Lancet Digit Health 2(10):504-505

6. Bonfiglio DG (2015) Quando un libro diventa un documento d'archivio. Le annotazioni manoscritte di un abate settecentesco sui calendari liturgici a stampa pubblicati dalla Diocesi di Padova. Paratesto 12:80-128. http://www.libraweb.net/articoli.php? chiave $=201505901 \&$ rivista $=59$

7. Tucci U (1973) Innesto del vaiolo e società nel Settecento veneto. Annales Cisalpines d'histoire sociale 1(4):193-231 
8. Lewis M. Lady Mary Wortley Montagu, Her Life and Letters (1689-1762). 1925 Hutchinson ISBN 978-1419129087

9. Timoni E (1714) An account of the history of the procuring of small pox by incision or Inoculation; as it has for some time been practised at Constantinople. Being an extract of a Letter from Emanuel Timonius, Oxon. and Patav. M.D. S.R.S. dated Constantinople, December, 1713. Philos Trans 29:88-91
10. Pylarini J (1714) Nova \& Tuta Variolas Excitandi per Transplantationem Methodus, Nuper Inventa \& in Usum Tracta... "A New and Safe Method of Communicating Smallpox ...". Philos Trans 29:207-210

Publisher's note Springer Nature remains neutral with regard to jurisdictional claims in published maps and institutional affiliations. 